\title{
Political Complexity in Nomadic Empires of Inner Asia
}

\section{Sergey A. Vasyutin}

Kemerovo State University

\begin{abstract}
The nomadic empires of Inner Asia are a unique historical phenomenon. Large mountain and steppe territories allowed hundreds of thousands of nomadic families to pursue their economic activities, creating the conditions that led to their integration into big imperial communities. The long border in the South with empire-civilization and world-system center China was one of the major 'challenges' for steppe people, the 'answer' to which was often the creation of semi-peripheral imperial polities, as only the common military capacity of the Inner Asia stockbreeders guaranteed them at least temporary military and political equality and even supremacy during periods of weakening of the Middle Kingdom. The established opinion on the similarity of the nomadic empires in this region is mostly the result of a long period of research on nomadic economies, social and political structures, and the relations between nomads and China (evolutionism, positivism, Marxism). In the last few decades, the concept of multi-linearity (non-linearity) of sociogenesis and politogenesis has been applied to this field of study, allowing us to focus on the peculiarities of the Inner Asia nomadic empires, creating a solution to the old issues surrounding the nature of the power systems among nomads, the existence or absence of statehood, and the typology of imperial structures according to their level of complexity.
\end{abstract}

\section{INTRODUCTION}

The issues concerning the characteristics of political regimes of medieval nomadic empires have provoked fierce debates among researchers and have become especially important during the last decade. The question of statehood among nomads and its specificity is still the most polemical issue (Khazanov 1981, 1984, 2010; Golden 1982, 1992, 2001; Barfield 1989, 2000, 2011; Kradin 1992, 2002, 2008, 2010, 2011a, 2011b, 2011c, 2014, 2015; Kradin and Ivliev 2014; Kradin and Skrynnikova 2006;

Social Evolution \& History, Vol. 18 No. 2, September 2019 92-114

(C) 2019 'Uchitel' Publishing House

DOI: $10.30884 / \mathrm{seh} / 2019.02 .05$ 
Mackerras 1990, 2000, 2004; Sinor 1990; Di Cosmo 1999, 2002, 2011; Klyashtorny 2003, 2010; Klyashtorny and Savinov 2005; Klyashtorny and Sultanov 2009; Rogers 2007, 2011, 2018; Sneath 2007, 2009; Legrand 2011; Scheidel 2011; and others).

The interpretation of the term state differs significantly among academic papers. Since the known characteristics of political organization among the nomadic empires of Inner Asia do not completely meet the accepted criteria of state power (i.e., developed legal and judiciary system, specialized bureaucracy in the central and provincial management apparatus, a fiscal system, etc.); the researchers use vague and unclear interpretations of nationhood. Daniel Rogers, in particular, defines state as 'any political entity in which authority is relatively centralized and hierarchical, and one in which control extends over a certain population and territory.' He adds that the state has one or more city-type centers, and 'individuals living in a state recognize it as politically independent of other such entities' (Rogers 1997: 250). The present stage of the discussion about the issues of statehood and the limits of political development of nomads demonstrates the necessity to define certain criteria to evaluate nomadic governing systems, their level of complexity, and typology.

\section{FEATURES OF NOMADIC EMPIRES}

We define classic (typical according to Nikolai N. Kradin) nomadic empires as territorially expanded polities of medieval nomads, formed in the steppe zone on the border with big agricultural civilizations. The dimensions of the nomadic imperial entities allow considering a certain military and administrative structure as one of the characteristics of such polities, namely:

- the staff of the khagan (khan) as the integrative center of the empire (command staff, the place of concentration of imperial 'functionaries,' counselors, service elite, and others);

- in terms of government, the 'center of the empire' was associated with summer and winter staffs of the Khagan which he would alternate;

- 'the center of the empire' was also associated with reserve trainings, cult activities and sacral ceremonies, diplomatic receptions, and festive activities;

- the division either into wings with separate centers or into wings with a center, or, as in one case, into a center with three wings (Malov 1959: 23);

- imperial princes with their titles;

- a decimal system which integrated tribes into the district hierarchy of military tumens and thousands of smaller units (the latter are not clearly defined in sources of nomadic origin; in the Early Middle Ages, for 
typical empires the description of the decimal system is presented in the Terkhin inscriptions - Klyashtorny 2010: 42);

- embassies of the center in the regional tribal nomadic groups and in the territories of non-nomadic populations (viceroys, fiscal officers, and military groups/camps in remote regions such as Altai, Tuva, Khakasia, Transbaikalia, Eastern Mongolia, and Manchuria, as well as in urban and agricultural communities in Eastern Turkestan);

- in some cases, a network of administrative personnel on the major trading paths and directions of geopolitical importance, similar to yam service in the Mongolian Empire.

This administrative system superimposed on a complex hierarchy built on the combination of political, ethnical, social and other principles. This hierarchy included:

- a khagan (khan) and ruling clan in which an important role was played by the aspirants to the supreme power and supreme imperial titles;

- people closest to the ruler through their status and aristocratic clans related to him;

- people from the khagan's suite (his 'command staff' could include nomadic aristocracy as well as representatives of agricultural populations, like the Sogdians and Chinese people, religious figures, talented commanders with non-aristocratic origins, personal army/guards, various servants, etc.);

- the tribes and clans that formed the elite layers of the empire (Luandi, Huyan, Lan, Xubu, and Qiulin in the Xiongnu polity; Ashina and Ashide in the Turkic Khaganate, Yaghlakar, Ediz, Kürebir, etc. in the Uyghur empire);

- the tribes of the dominant ethnic group (Xiongnu, Turk, Uyghur);

- dependent tribes whose armies were a part of imperial army;

- dependent clan and tribe unions with low status (such as tribe groups who could subject to tribute and different fees; the Khitans for the Turks and the Uyghur);

- subordinate semi-settled and sub-taiga populations on the periphery of the empire (they provided the empire with agricultural products, furs, metal, etc.);

- farmers and agricultural communities living in the steppe (traders, refugees, people captured in China, etc.); these communities could be quite large: emperor Taizong bought 80,000 Han people from the Turk for gold and silk. They were in the Khaganate during the period of the Sui falldown (Bichurin 1950: 256); in the other case, in 698, Qapaghan Khaghan attacked the prefectures of Zhaozhou, Dinzhou and others in the borderline county of Hebei and captured 80 to 90 thousand people (Liu Mau-tsai 1958: 163). 
Relationships between the khagan and the tribe leaders and their lineages played a key role in the inner organization of the empire. Maintenance of high status was impossible without loyal powerful tribes and tribe groups. At the same time, one should not forget that some quite severe methods of submission could have been used by the center towards some units of the imperial hierarchy.

\section{POLITICAL INSTITUTIONS IN NOMADIC EMPIRES}

Which criteria should be chosen to determine the level of complexity and the distinction between the chiefdom (in various forms) and the state (or early state), or alternative political forms among the nomads of Inner Asia? For researchers, the answer to these questions is complicated by the fact that in all nomadic empires, the ratio between pre-state and early state components of power is inconstant and fluid. The development of nomadic empires was not unilinear and single-vector. The examples of Xiongnu country, Rouran, Turk, and Uyghur Khaganates show in the first stages the trends towards centralisation of the political system. However, these trends could be alternated by separatist transformations (the strengthening of local leaders, domestic strife, riots, etc.). Sometimes, these contradictory trends occurred at the same time. In the Mongolian empire, during the second third of the thirteenth century, the formation of the institutions of early statehood was combined with the strengthening of the ulus level.

The imperial formations of nomads periodically returned to traditional clan-tribal institutions of governing when the mechanisms of subjugation of nomads of the steppe and the remote exploitation of agricultural peoples stopped or became inefficient (Kradin 2002: 191-193, 199-200, 230-231). The power of a nomadic leader lost the imperial character and the chief actions were aimed, first of all, at preserving his status among the elite.

Another destructive process typical for nearly all nomadic empires was related to over-production of political elites - the growth of the number of adult men in the leader's clan who wanted to participate in the governing of the empire, and aspired to supreme power (concept of Nikolay Kradin [1992: 152; 2008: 113, 118; 2011b: 433-437; Kradin and Skrynnikova 2006: 485]). The nomadic polities' resources were too limited to meet the needs of growing governing patronymy and nomadic leaders could not give means and privileges to their relatives and chiefs forever. The 'over-production' of elites resulted in domestic strife and in some cases in the division of the common political territory into several autonomous units. This was the situation for the Xiongnu Empire, which was divided into Northern and Southern confederations, and of the united Turkic Khaganate, which in 603 was split into the eastern and western khanates, with different tribal structures and elites. In this way, the large nomadic polities were not safe from destruction and conquest. 
Returning to the discussion about the existence or absence of state in medieval Inner Asia, one should remember that governing systems of the nomadic empires are complex and many-sided phenomena that cannot be described with simple definitions. The attempt to overcome the dichotomy of pre-state and state status of the imperial polities of nomads using the concept of dual nature of nomadic empire (Kradin 2002: 240249) is a good one but does not give full answers.

In this regard, we suggest not limiting the discussion to this dual nature but also take into account the multi-component power structure of nomadic empires. In these pastoral political formations, the institutions of different levels were adapted to and interacted with clan and tribal structure, super-tribal (chiefdoms, tribal confederations), imperial and/or early state hierarchy with varied proportion at different historical periods. The internal differentiation of governing activity in nomadic empires demonstrates varying components of the nomads' political culture.

The most typical characteristics of clan power were: leadership in the clan, lineage, and primary tribe (the system of social relations was mostly based on family relationships), based on the traditional authority of the oldest person in the patronymy; submission to the head of the clan (lineage) is based on the traditional acceptance of his power and personal authority as a ruler, the right of judgments, priority in defensive actions and invasions; a combination of reciprocity and redistribution in his governing with the focus on reciprocity relationships, when prestigious economy involves the maximum number of tribe members; regulation of the relationship between the power and the population using traditions (common law, household and military rituals); limitation of the leader's sacral power at the clan-tribe level with local religious traditions and rituals.

The super-tribal nomadic polities of Eastern Asia are marked by: a super-local level of integration with a chief clan (e.g., the Karluks) or tribal group (the Uyghur and their allied tribe, the Xueyantuo) or temporarily charismatic leaders appearing (early Khitan); eritable power (e.g., the Toghuz-Oghuz with the chief clan Yaghlakar); a large number of members of the confederation (at least tens of thousands); a personal supreme power, the charisma of the ruler, and dependence on the successful political and military activity.

In the imperial confederations of nomads in the steppe, the following characteristics predominated: large steppe polities united all the peoples 'drawing the bow' with population of no less than one million people (Kradin 2011b: 437); centralization in the form of a military and hierarchical system of subjugated tribes and different ethnic groups with a corresponding distribution of power among the members of the ruler's clan and the leaders of the subjugated tribes, creation of the center and tribaladministrative divisions (wings); a leader with wide-ranging powers 
in military-administrative, religious-sacral, ceremonial fields (his judicial functions are not usually clear); dependence of the rulers position and the whole empire's stability on their military success; imperial sacralization of the supreme power as a mediator between the Heaven and the nomads; use of writing in political activity and creation of ideologemes and political constructions of a brave khagan-commander, uniting the 'peoples' of 'four corners'; vertical subordination and strict discipline in the army to maintain the peace in the steppe, and the realization of external political tasks of empire; the creation of an imperial dignitary suite for the leader, socialprofessional groups (retainers, personal guards, servants), including expats (the Sogdians, the Chinese, etc.) of various origins (Kradin 2011b: 431-432; Biran 2015: 2-3; Vasyutin 2015a: 23).

The study into the transition of nomadic empires into different forms of statehood allows for the definition of some novel components: the ruler with wide political and ritual-sacral functions, synthesizing the roles of a nomadic chief and a king of agricultural people; synthesis of redistributive mechanisms, trade fees, borrowed from the tax experience of agricultural states; multiethnic state machinery with a clearer function division and branch hierarchy; a tendency to formalize state activity (official paperwork, regimentation of different fields of civil servant life, etc.); preservation of some nomad autonomy (army base and power support), and special governing mechanisms used towards them including fiscal fees and tribute (Vasyutin 2015a: 22-24).

In every large nomadic polity, the proportion of power components was different and could quickly change: both strengthening of the supercomplex chiefdoms and states activity and weakening of the imperial organization and strengthening of local tribal structures.

In the nomadic empires, clan and tribal components of power often preserved their former functional meaning. It was quite common for them to transform into wider redistributive power functions according to new governing tasks. Several types of relationships are formed within the framework of the prestigious economy: 1) the leader - members of the ruling clan - court aristocracy; 2) the ruler and the dominant ethnic group; 3) the chief - the tribal leaders, and the settled societies rulers; and 4) the tribal leader - the tribal nobles - other members of his clan and lineage (Vasyutin 2015a: 22). In almost all cases these political relations had a key role in providing stability to the empire and in the efficient governing of the imperial polities of nomads.

In Turkic Khaganate, successful military actions and redistributive giving of material goods secured the khagan's reputation and promoted the sacralization of the supreme khans of khaganates which made them the most important resource of government. The Turks elite received a large portion of gifts delivered from China. The Xiongnu example shows that 
this resource was limited though and was distributed only among a close circle of relatives, aristocracy, retainers, and more loyal tribal chiefs. At the same time, the tribal chiefs' actions were directed towards common nomads as well, in the form of new pastures and part of the spoils of war during invasions (Kradin 2002: 108-109; 321; 2010: 319-322; 2014: 140-141). Being a kind of 'banker', the ruler had to satisfy a maximum number of clan-lineage groups within the empire to preserve his influence over them. Redistributive activity complemented other governing structures (military hierarchy, vice-regents and military posts in conquered lands, judiciary system). Conspicuous consumption, typical for Turks khagans had the same goal, especially during the official activities and rituals (reserve training, religious holidays, reception of ambassadors, funerals of khagans, and prelacy). The description of the reception of Byzantine ambassador Zemarchus is especially emblematic - during the reception, the Byzantine ambassador was shown the khagan's riches. The public character of such activities was meant to create an image of importance and success for khagans (Vasyutin 2015a: 22).

\section{BALANCE OF POWER}

The centralized imperial structures of the Mongolian nomads were built by consolidation of nomadic societies into a common polity, conquest of nomadic tribes or forcing them during military conflicts with settled neighbors, invasions and occupations, building the system to control the conquered peoples. This mostly predetermined the domination of military functions over civil ones. The war transformed into one of the major tools of governing. It is not for nothing that the leader's positive image was created in the context of his heroic military victories (that was one of the tasks of the inscriptions in honor of Bilge-khagan and Kul-Tigin).

How did the military-hierarchic structure contribute to the stable authority and power of chanyus and khagans? On the one hand, the nomads showed strict discipline in armies, which provided additional governing tools to the supreme nomadic leader. On the other hand, Chinese chroniclers defined the nomadic military discipline and organization on a caseby-case basis. In some cases (the Uyghur, the Khitan) the efficiency of army management, tactic methods and military success were described (Bichurin 1950: 311, 317-318; Ye Longli 1979: 43-44, 66, 74-75, 7778ff.; Tiuriumina 2007: 44, 49, 53-54, 54-55, 61, 65, 67-68, 85, 86, 87, 93), but there are a lot of examples of the opposite situation as well (Ye Longli 1979: 45, 48, 56-57; Tiuriumina 2007: 58, 66-67, 85, 97, 106). Especially numerous negative opinions about nomadic discipline in Chinese sources were given during crises of empires. For example, poor preparation, the appointment of unqualified commanders, and the flight of the Liao army during the battle with the Jurchen in 1115 while the Em- 
peror Tianzuo and his avant-guard were struggling with the enemy in snow blizzard (Ye Longli 1979: 180-182; Tiuriumina 2007: 120-121). It is interesting that Chinese counselors gave their opinions about the poor organization of the Turks' military system ('disgust to titles and decorations,' 'disrespect to their chiefs,' 'disrespect to the laws and orders,' etc.) both during the active Turks conquests and during the khaganate's stagnation and decline (cf., i.e.: Liu Mau-tsai 1958: 12, 130). It is evident that such evaluations mostly demonstrated an extrapolation of the opinions about army organization in China to the nomadic world and the stereotypes in descriptions of 'northern barbarians' formed in the Chinese written tradition.

In the Turkic Khaganate period, texts related to the khagan and other elite groups reflect the important pages of military, political, and ethnic history, the evaluation of predecessors' activity, acts of heroism of those to whom the inscription was dedicated. The sky born leader's power had a divine origin; he was the central person in the imperial ceremonies, religious and socio-cultural activities, etc. The History of Sui dynasty shows how the supreme power of the Turks leader was presented in a letter of Shabalue Khagan to the emperor Gaozu: '... Born in the Dragon Year by the wise Haven and blessed Haven Son of the Great T'u-küe Empire...' (Liu Mau-tsai 1958: 50).

One should note a certain transformation highlighting the growing role of ideological texts in the steppe societies of Inner Asia in the Early Middle Ages. If the Turks commemorative runic texts provided information on the khagans' governing (Bugut stele, Bilbe-Khagan inscription) and their counselors (inscriptions in honor of Kul-Tigin and Tonyukuk), the Uyghur ones glorified the governing khagans, and stones with inscriptions marked the territories conquered by khagans (Klyashtorny 2010: 41, 63 ). Thus, stones with runic inscriptions transformed from instructive epitaphs to propagandist symbols of the greatness and supremacy of the new steppe owners. Abaoji, the founder of the Liao Empire, understood well the ideological meaning of such texts. During his campaign in Mongolia in 924-925, he ordered the removal of one of the inscriptions of the Uyghur khagan and the creation of an inscription glorifying his acts in Khitan, Turk and Chinese languages (Wittfogel and Feng 1949: 576).

The large nomadic empires in Eastern Asia (Liao and Yuan) appeared mostly as a result of the invasion of large territories in China and other agricultural territories, the functions of the nomadic leader were more diluted progressively in bureaucratic activities of state institutions. However, the new nomads' experience of tax and fees collection by agricultural elites, the creation of administrative institutions and bureaucracy needed an approbation of such activities by several nomad generations. The evolution of power in the Liao Empire is exemplary. During the 
Abaoji government the tributes from the dependent nomadic and settled populations were limited to cattle, silk, and canvas (Ye Longli 1979: 240; Tiuriumina 2007: 56-57). A more progressive fiscal policy was pursued only towards the Chinese enclaves in Khitan clan lands, where Han settlements and cities with official institutions, trading, and salt and iron ore mines were located (Ye Longli 1979: 42, 43, 348, comment 11; Tiuriumina 2007: 47, 18, 187). The engagement of Chinese people into the administrative system was not for nothing. Even during the Deguang government, the Khitan emperors received their main income through conquests, robberies, and gifts from the Late Qin and other Chinese states in silk, gold and carts (Taskin 1984: 198).

Only in the middle - second half of the tenth century, in the Liao Empire the bureaucratic activities spread among the nomads progressively (taxes, state works, border service, etc.). During the rule of Shengzong and the 'empress dowager' Yanyan, this resulted in a need for a qualified bureaucracy, reconstruction of the system of exams for civil officers, and the opening of educational institutions for the Khitan elite (Kradin and Ivliev 2014: 238-240). In the eleventh century, the empire became a nomadic-settled state. During the rule of Emperor Xingzong (1031-1055), he issued a series of orders (1040-1041) in which he forbade conferring a title to people who had broken the law, forbade civil servants to leave the service without permission, gave the order 'not to fuddle' at work, and not to take expensive things from the treasury. For the hunting in forbidden places, the peoples were punished with some hundred lashes. At the same time the Liao emperor also appealed to people who 'understand how to govern the people' to serve (Tiuriumina 2007: 103). The transition to state methods of governing was a long process in the Mongolian empire as well. Stable state institutions (taxes and respective bureaucratic system) did not appear until the middle - second half of the thirteenth century. In Liao, the same process continued until the tenth - early eleventh century.

Thus, the power in nomadic societies, especially in large imperial polities, represented a complex phenomenon. Nomadic empires were prototypes of the transition to state models of political organization. In those societies the traditional tribal system of governing transformed into more hierarchical and complex structures with a large power for the supreme chief. The components of the traditional system of power served the basis for the governing practices of nomadic leaders. At the same time, the extent of imperial governing provoked some innovations in governing methods. This synthesis reflects the peculiar character of nomadic empires controlling mostly steppe territories. However, the attempts 'to take a step' towards a state in such polities provoked a crisis and imperial decline. The Uyghur Khanate with its early statehood was an exception. 
The history of the Uyghur shows that one of the most important criteria of complexity of nomadic empires is urbanization and settled agrarian societies in the steppe area. Urbanism is not a universal criterion of the transition to statehood (cf., i.e., Kradin 2006: 94-95). Towns appeared quite early, while the formation of state institutions needed several decades to emerge. But as for civil servants, urbanization since it drastically changes the economic structures of the steppe territories, creates taxation institutions along with respective administration in nomadic polities, and the creation of settled administration (Kradin 2011d; Vasyutin 2015c).

The stable state activity was based on the long process of assimilation of the agricultural peoples' governing experience which became necessary after the conquest of settled population's territories. The assimilation of this experience by the nomads themselves is a separate issue. In all conquest empires this was limited and never fully realized. The limitation of state governing methods was caused not only by the fact that lower-status nomads formed the bulk of the army, but also by the remnants of traditional paradigms and practices of the nomadic elites, close religious, ritual, and socio-cultural relationships between the elite and common nomads (Vasyutin 2015a: 24-25).

\section{SUPERCOMPLEX CHIEFDOM}

Since the mechanisms of tribal power were characteristic for the pastoral nomadic societies, and state institutions in steppe territories were an exception, chiefdom could hypothetically be called the basic characteristic of nomadic empires. The chiefdom according to its type (simple, complex, compound, maximal, etc.) was considered as a step of politogenesis between acephalous tribal communities and the state. As for the nomadic empires of Inner Asia, the use of the chiefdom concept (in the version of supercomplex chiefdom) is thoroughly justified by Nikolay Kradin. The Xiongnu Empire and imperial nomadic communities played the role of a test ground (Kradin 1992, 2002, 2003, 2008, 2010, 2011a, 2011b, 2011c, 2014, 2015, etc.). For Kradin, the basic model was the concept of a complex chiefdom as an association of secondary tribes in a common union with a common system of governing and cults. In neo-evolutionism, the complex chiefdom was considered as a step from which agricultural societies could potentially transform into a state. Therefore, a complex chiefdom can be defined as a stage of state formation. Kradin insisted on the pre-state level of the Xiongnu Empire and believed the nomadic empires to be large tribal confederations which were much more complex than the complex chiefdoms in terms of human resources, territory, and military potential.

Using this approach, he concluded that imperial unions represented chiefdoms at their maximum level of complexity. As such, he introduced a new definition to reflect the larger dimensions and hierarchies of no- 
madic empires - supercomplex chiefdom. Although, Kradin himself recognized in his papers that 'the super-complex chiefdom of nomadic empires is a real prototype of an early state...' (Kradin 2002: 245), in terms of concepts, he defines the steppe empire polities as transitional but not yet achieved the level of early statehood. The complexity of the power system in the Xiongnu Empire, the first nomadic empire of Inner Asia, is highlighted by the numerous settlements found within its territory. Although, today we know only one proto-city (Ivolga site), located in the empire periphery, while in the settlements with ramparts in the Mongolian steppes excavations revealed platforms with tile roof dwellings, complex constructions of gates, but no evidence of any archaeological layers or specific artifacts representing craft and trade, or any administrative and military purposes of those constructions (Kradin et al. 2017).

The definition of Xiongnu as a supercomplex chiefdom can be used as the basic concept for the imperial confederation of nomads in Inner Asia. However, this does not mean that alternative opinions can be ignored. Here, we will consider the opportunity of employing other definitions in order to interpret nomadic empires using the example of Early Medieval polities.

The Turkic Khaganates had a complex power structure and can serve examples of stratified societies, but judging by some key characteristics, they cannot be considered as examples of classic statehood, or even early forms of state. During different periods of the Turkic Khaganates' history, their formal characteristics appear more like transitional or primitive statehood. However, in these definitions, the line between complex forms of chiefdom and statehood is blurred.

Why can the imperial khaganates not be described as states? First, the khaganates did not have specialized civil servants. 'Administrators' were mostly relatives of khagan or tribal aristocracy, and their governing activity, especially at the provincial level, was not the result of special training (except military functions). It was not separated from other activities, it did not become a profession, and the people who had these responsibilities cannot be considered as professional bureaucrats.

Second, they did not have common imperial written or oral legal acts. To deal with any legal case, the authorities mostly based their opinions on ordinary law traditions of different ethno-political groups. The chiefs of subjugated tribes still had their autonomy in legal procedures within their nomadic communities. The supreme chief alone had special judicial power in the military field.

Third, a common fiscal network and consistently applied norms for fiscal fees did not exist. The 'taxes' were mostly collected from the agricultural peoples controlled by khaganates, and in steppe, tributes, irregular forms of 'payment' of authority services (some cattle for ritual actions and campaigns, organization of feasts, symbolic gifts, etc.). The attempts 
to introduce some elements of regular fiscal taxes made by the Chinese and the Sogdians during the reign of Qilibi Khan caused social tensions in the steppe society and led to riots and open fighting against the Turkic power which resulted in Khaganate defeat and surrender to China. Similarly, the tribute and tax, the engagement of the Sogdians during the rule of Qapaghan Khaghan (Malov 1959: 20; Liu Mau-tsai 1958: 169-170) were some of the reasons for riots among dependent tribes in 714-716 which in turn caused a serious crisis in the Second Turkic Khaganate. The ruler did not have enough political means to bring them under regulation and control so both Qapaghan and Bilge Khagan with Kul-Tigin had to bring loyalty back with 'fire and sword.'

Comparing the basic elements of political culture in Turkic Khaganates demonstrates the typical chiefdoms traditions in the khaganate. The state institutions were limited and performed by a small number of executives. However, the Turkic polities of the middle of the sixth - first half of the eighth century surpassed the complex and maximum chiefdoms in complexity and population numbers. In Turkic Khaganates, there were dozens of tribal confederations and settled societies subjugated or integrated into the empire. The population of the Mongolian steppes and adjacent territories in the ancient and the Medieval periods varied from 800 thousand to $1.2-1.5$ million people (Kradin 2002: 71-79; 2011b: 437), while in compound chiefdom the average was tens of thousands people. Larger societies existed but they did not compare to the nomadic empires in territory size. The control over the wide territories and numerous dependent polities surely needed a more complicated form of governing than that of a chiefdom.

The institutional aspect of imperial origin in khaganates was a military-hierarchical system. This system included decimal principle, discipline, subdivisions, commanders, separate armies, strategy of military actions and was at the same level of organizational complexity as armies of many agricultural state societies (kingdoms of Western Europe, early states of the Slavs and the Scandinavians, etc.). In contrast to the internal social relations, the military organization of the khaganate was the basic institution for supporting the nomadic polity (Klyashtorny 2003: 469-470). Only in comparison with the armies of the leading empire-civilizations (Rome, the Byzantine Empire, Iran, and China) can a difference be noted in tactical training, discipline, weapon variety, and the strategy of collective actions between nomads and agricultural states armies. But, the nomads could win a fair fight even against the armies of these world-system centers (the semi-periphery military advantage of more complicated societies is a separate topic). It is evident, that in its structure the power in Turkic Khaganates did not have all the characteristics of statehood but was at the chiefdoms level of political integration in its complexity. 


\section{ANALOGUES AND ALTERNATIVES}

Political anthropology presents a wide range of concepts to evaluate different power systems - different types of chiefdom and states, analogues and alternatives to chiefdoms and states (Claessen and Skalnik 1981; Claessen and Velde 1987; Claessen 1989, 1991, 2010, 2011, 2014; Carneiro 1981, 1992; Earle 1987, 1997, 2011; Kradin 1995, 2009; Bondarenko 2001, 2005, 2006, 2008, 2011; Bondarenko, Grinin, and Korotayev 2006; Grinin 2006, 2008, 2009, 2011; Grinin and Korotaev 2011; Skalnik 2009,2011 , etc.), which allows a choice between various theories to evaluate the Turkic Khaganates. Some current researchers rely on multilinearity (nonlinearity) of politogenesis and a variety of political structural forms. A state is not alone at the top of the political development, as history shows examples of no less complicated forms of political existence without clear attributes of state institutions. Such polities are usually identified as analogues or alternatives to a state (Bondarenko 2001, 2005, 2006, 2008, 2011; Bondarenko, Grinin, and Korotayev 2006; Grinin 2006, 2008, 2009, 2011; Grinin and Korotaev 2011). Some researchers suggest more specific terms for complicated hierarchic formations, like, for example, a homoarchy (Bondarenko 2005, 2006, 2011).

Multilinearity can be observed in the political history of Turkic Khaganates. The Great Turkic Khaganate was the largest empire in the territory after the Mongolian empire. Compared to Genghis Khan's system, the power in the khaganate was less structured and lacked a common ruling system (the Western part of the khaganate developed autonomously). The internal conflicts between Ashina clan members appeared relatively early, leading to internal struggle and the division of the khaganate into two separate polities. In neo-evolutionalist terms, the First Turkic Khaganate can be defined as an imperial-xenocratic homoarchic structured alternative to a state. Taking into account more developed governing activities in the khagan's lands with agricultural and city populations (urban areas in Eastern Turkestan and Zhetysu) one can speak about a territory division according to the complexity of power organization in the empire. State institutions existed only in the agricultural area of empire. Political institutes did not change in the steppe part of the khaganate. This form can be described as a marginal (marginal-peripheral) state (this model can be included in the concept of situational state as defined by Anatoly M. Khazanov [1984]). In the khaganate center transitional political and socio-cultural activities predominated. In the provinces, where the central power was represented by shads and tutuks who mostly interacted with tribal chiefs and leaders of large tribal confederations, the need of the state activities was low.

The Eastern Turkic Khaganate was changing to become more complicated. The main factor in the transformation of the Eastern Turkic Khaganate was the Chinese and Sogdian communities on the empire territory. 
As mentioned above in reference to the purchase of 80 thousand Chinese people by Tan'g emperor Taizong from the Turks while a big part of the Han people who were against Tan'g stayed in the steppe. When the Turks were defeated in 630 and surrendered to Tan'g empire, Samarkand and Bukhara Diaspora members overpassed the Chinese border. The Bukhara Diaspora alone consisted of 5 thousand families (Klyashtorny 1964: 119).

It was an active political actor in Eastern Asia but it could not compete with a new powerful empire in China (Tan'g empire). An attempt to adapt the nomadic semi-periphery to the growing economic and military power of China by means of complicating political activity (engagement of settled community members to govern) showed that this political system of the Turk was not ready to overcome the threshold of complexity (Vasyutin 2015b: 398). The political hierarchies of this khaganate can be defined as an analogue to the maximum chiefdoms of the agricultural people.

Many nomadic peoples experienced multi-directional processes in their history (growing, decline, stagnation, crisis, etc.). The Second Turkic Khaganate (689-744/745) is an example of such trends and processes. After Qapaghan-Khagan's failure to create a huge empire comprising Eastern Turkestan, Dzungaria, Zhetysu, Sayan-Altai, the land bordering with Tan'g dynasty in the South from Goby, Ordos, and other territories in the Eastern Khaganate, the military and political resources and energy of Bilge-Khagan, Kul-Tigin, and Tonyukuk were mostly directed towards the subjugation of the rebellious tribes and the appeasement of the steppe and not towards the development of the khaganate into a more complex structure, though the Turks did not loss the potential (Bilge-khagan's wish to build a city and spread Buddhism among the nomads was attributed to a counselor). In this case, the trend towards an imperial-xenocratic model with marginal-peripheral statehood was replaced by the one towards a smaller polity, which was a pre-state hierarchical tribal confederation using military-administrative control and fiscal collections from the subjugated population and which existed until the first conflicts inside the governing clan (Vasyutin 2015b: 400-405).

Taking into account the mobility of the nomadic political system, multidirectional trends towards both complication (control of the transit trading, subjugation of the agricultural people or military-political control of settled populations) and simplification (division of the empire into several parts, subjugation of the Chinese elites, disorganization of power as a result of riots and external aggressions). With such dynamic changes, the ruling system in the Turkic Khaganates at different stages of its development could be described as ranging from tribal union confederation and nomadic analogue of compound chiefdom to a homoarchic alternative to a state. The loss of nomadic staff control over the tribes or a decline of empire led to hierarchical structures (Bondarenko 2006: 164-166, 168-169), until a new nomadic empire would emerge in the steppe. 
The Uyghur Khaganate experienced a more stable trend of increasing complexity. The building of cities and fortresses (the hierarchy of settlements included a capital city, regional cities, staffs, fortresses, trading and market development in Mongolia, conversion to Manichaeism and its spread among common people, the creation of a hierarchic governing system, tax collection from nomads - all this definitely shows a transformation of the Uyghur Empire into an early state. The further development of the khaganate includes traditional forms of statehood. But this process failed to be completed by the time when the Uyghurs were defeated by the Kirghiz, which is why the transitional state forms remained (Vasyutin 2015b: 405-414).

As mentioned above, the Liao Empire with Yuan represents the most complicated development of Inner Asia nomadic polities. The Khitan Empire, which included wide territories with settled people and nomadic populations (Bohai, North-Eastern China, the lands in the South and North from Goby) and which experienced several political transformations at the early tenth century, the Khitan union was a confederation of nomadic chiefdoms and tribes. Conquest and power centralization led first to the creation and development of a dual system which in its turn led to the establishment of traditional statehood institutions based on the synthesis of Khitan political activities and Chinese political culture (Kradin and Ivliev 2014: 224248). In my opinion, a complete establishment of a state occurred during the rule of Shengzong and Xingzong. These transformations resulted in a complex political changes in the Liao Empire, which was a typical settled empire with a traditional state governing system on the territory of the Southern administration and a peculiar transitional form of a state system including tribal confederations and chiefdoms in its structure inside the Northern administration (Vasyutin 2015b: 414-415, 424-425).

Finally, the political anthropology and concept system of this research allow us to outline the solutions for the debated points regarding the evaluation of Inner Asian nomadic empire institutions in the Early Middle Ages. The key solution is to use such definitions as nomadic analogues of chiefdoms, homoarchic alternatives to a state in the Turkic and Uyghur Khaganates history, and early stages of the Liao empire development. These are model types and they do not limit a researcher to strict definitions of terms like supercomplex chiefdom or early state which allow for various interpretations but do not provide a clearer understanding of the system complexity level according to the elaborated scale of political integration types and the models of related political structure.

CONCLUSION: TYPES OF INNER ASIAN NOMADIC EMPIRES

This section presents two basic models of nomadic empires typology. The first model is related to the traditional super-tribal military-political un- 
ions of nomads, controlling the steppe territory and some adjoining enclaves of agricultural people. It can be described as a traditional or classic model, and describes two sub-types. The first subtype is presented by imperial-xenocratic analogues of agricultural complex chiefdom and homoarchic structures. The genesis of such empires is a result of the subjugation by other consolidated tribal groups of nomads and the creation of an imperial ethno-political hierarchy. The practical tasks of governing the steppe communities forced the elites to form territorial governing organs (center and wings). The typical principles of further functioning of the described imperial formations are mostly based on the sacral power of political leader, military subordination, and discipline. Prestigious economya certain mechanism of consolidation of imperial prelacy and chiefs around the supreme leader at the expense of the resource-using of the biggest civilization in Eastern Asia (China) and mostly controlling the subjugated tribes. The controlled lands with agricultural populations outside the steppe (some oases in Eastern Turkestan, agricultural colonies in Ordos, settled communities in Southern Siberia) and settled communities in the territory of Mongolia do not change the xenocratic character of imperial integration since their resources can be compared to the economic, military-political, and cultural potential of China. The Eastern Turkic Khaganate was a historical example of such a model.

A more complicated option of the primary model (the second subtype) is a steppe imperial state model. In the history of Inner Asian nomadic empire, such an empire in the steppe territory appeared only once. This was the Uyghur khaganate where along with the significant import of silk and coins from China an inner nomadic-settled economy developed, with a fiscal system and a relevant power system.

The second model can be defined as secondary or conquest (definition of N. N. Kradin [2003]). The empires of this type were large and covered steppe territories with military and political control of large territories with settled population or direct governance of these territories. In the conquest model, the political elites have income not only from invasions, tribute, and gifts from distant settled populations, but also from collecting tax and fee from conquered agricultural population. As in the case of the first model, two sub-types of conquest empires can be defined. In the first case (conquest imperial-xenochratic model) the political center of the empire stayed in the steppe but to solve the governing tasks it needed a military-administrative system copying the political centers on the remote sufficiently large and important territories, and tribute-fiscal policy on the conquered territories.

The First Turkic Khaganate serves an example of the first subtype, since it conquered territories from Manchuria to the Black Sea with a large number of settled populations in Central Asia, the Caucasus, for- 
est-steppe and sub-taiga zones of Siberia. During the Second Turkic Khaganate, Qapaghan-Khagan tried to recreate a conquered empire but after his death the elite chose a way of development close to the traditional model with extremely limited xenochratic tasks towards China. The first subtype was in the Liao Empire during Abaoji, Deguang, and Wuyu (the first half of the tenth century) and the Mongolian mega-empire before ulus states.

The second subtype of conquest nomadic empires was marked by moving the political center to the territory of settled civilizations and the progressive transformation of political institutions of nomads into a traditional state with fiscal action towards agricultural-urban population and in an adapted form to nomads. The example of a typical conquest imperial-state formation or nomadic-settled state was Liao dynasty in the second half of the tenth - beginning of the twelfth century and Yuan empire.

It should be noted that my version of the two basic models of nomadic empires as well as the general typology of political system in Eurasian nomads (Vasyutin 2003, 2010) has format of 'ideal type.' The forms of power organization and ways of political adaptation in nomads both in different and quite similar natural-climatic and social-cultural conditions could be both quite similar and very different.

\section{REFERENCES}

Barfield, T. 1989. The Perilous Frontier: Nomadic Empires and China, 221 BC to $A D$ 1757. Cambridge: Blackwell.

Barfield, T. 2000. The Shadow Empires: Imperial State Formation along the Chinese-Nomad Frontier. In Sinopoli, C., D'Altroy, T., Morrision, K., and Alcock, S. (eds.), Empires (pp. 10-41). Cambridge: Cambridge University Press.

Barfield, T. 2011. Something New Under the Sun: The Mongol Empire's Innovations in Steppe Political Organisations and Military Strategy. In Enkhtuvshin, B. (ed.), Nomadic Civilizations in Cross Cultural Dialogue (pp. 93-104). Ulaanbaatar: International Institute for the Study of Nomadic Civilizations.

Biran, M. (ed.) 2015. Nomads as Agent of Cultural Change: The Mongols and Their Eurasian Predecessors. Honolulu: University of Hawai'i Press.

Bondarenko, D. M. 2001. Pre-Imperial Benin. Formation and Evolution of the System of Social and Political Institutions. Moscow: Institute for African Studies of the Russian Academy of Sciences; Centre for Civilisational and Regional Studies of the Russian Academy of Sciences. Original in Russian (Бондаренко, Д. М. Доимперский Бенин. Формирование и эволюиия системы соииально-политических институтов. Москва: Институт Африки РАН; Центр цивилизационных и региональных исследований РАН).

Bondarenko, D. M. 2005. A Homoarchic Alternative to the Homoarchic State: Benin Kingdom of the $13^{\text {th }}-19^{\text {th }}$ Centuries. Social Evolution and History 4 (2): 18-88.

Bondarenko, D. M. 2006. Homoarchy as a Principle of Social-political Organization (The Problem Settling and Introduction of Concept). In Grinin, L. E., 
Bondarenko, D. V., Kradin, N. N., and Korotaev, A. V. (eds.), The Early State, Its Alternatives and Analogues (pp. 164-183). Volgograd: Uchitel. Original in Russian (Бондаренко, Д. М. Гомоархия как принцип политической организации (постановка проблемы и введение понятия). Раннее государство, его альтернативы и аналоги (с. 164-183) / Ред. Гринин, Л. Е., Бондаренко, Д. М., Крадин, Н. Н., Коротаев, А. В.. Волгоград: Учитель).

Bondarenko, D. M. 2008. Kinship, Territoriality and the Early State Lower Limit. Social Evolution and History 7 (1): 19-53.

Bondarenko, D. M. 2011. 'Homologous Series' of Social Evolution and Alternatives to the State in World History (An Introduction). In Kradin, N. N., Korotayev, A. V., and Bondarenko, D. M. (eds.), Alternatives of Social Evolution (pp. 335-345). $2^{\text {nd }}$ ed. Saarbrükken: Lambert Academic Publishing.

Bondarenko, D. M., Grinin, L. E., and Korotayev, A. V. 2006. Alternatives of Social Evolution. In Grinin, L. E., Carneiro, R. L., Bondarenko, D. M., Kradin, N. N., and Korotayev, A. V. (eds.), The Early State, Its Alternatives and Analogues (pp. 15-36). Volgograd: Uchitel. Original in Russian (Бондаренко, Д. М., Гринин, Л. Е., Коротаев А. В. Альтернативы социальной эволюции. Раннее государство, его альтернативы и аналоги (с. 15-36) / Ред. Гринин, Л. Е., Бондаренко, Д. М., Крадин, Н. Н., Коротаев, А. В. Волгоград: Учитель).

Bichurin, N. Yu. 1950. Collected Information about the Peoples Inhabiting Middle Asia in Ancient Times. Vol. 1. Moscow - Leningrad: Acad. of Sciences USSR Press. Original in Russian (Бичурин, Н. Я. Собрание сведений о народах, обитавших в Средней Азии в древние времена. Т. І. Москва Ленинград: Издательство АН СССР).

Carneiro, R. 1981. The Chiefdom as Precursor of the State. In Jones, G., and Kautz, R. (eds.), The Transition to Statehood in the New World (pp. 37-79). Cambridge: Cambridge University Press.

Carneiro, R. 1992. The Calusa and the Powhatan, Native Chiefdoms of North America. Reviews in Anthropology 21: 27-38.

Claessen, H. J. M. 1989. Evolutionism in Development: Beyond Growing Complexity and Classification. In Gingrich, A., Haas, S., Haas, S., and Paleczek, G. (eds.), Kinship, Social Change and Evolution (pp. 231-247). Horn-Wien: Verlag Ferdinand Berger \& Söhne.

Claessen, H. J. M. 1991. State and Economy in Polynesia In Claessen, H. J. M., and van de Velde, P. (eds.), Early State Economics (pp. 291-325). New Brunswick \& London: Transaction Publishers.

Claessen, H. J. M. 2010. On Early States - Structure, Development, and Fall. Social Evolution \& History 9 (1): 3-51.

Claessen, H. J. M. 2011. On Chiefs and Chiefdoms. Social Evolution and History 10 (1): 5-26.

Claessen, H. J. M. 2014. From Incidental Leaders to Paramount Chiefs: The Evolution of Socio-Political Organization. Social Evolution \& History 13 (1): 3-41.

Claessen, H. J. M., and Skalnik, P. (eds.) 1981. The Study of the State. The Hague: Mouton.

Claessen, H. J. M., and de Velde, P. V. (eds.) 1987. Early State. Leiden: Brill. 
Di Cosmo, N. 1999. State Formation and Periodization in Inner Asian History. Journal of World History 10 (1): 1-40.

Di Cosmo, N. 2002. Ancient China and its Enemies: The Rise of Nomadic Power in East Asian History. Cambridge: Cambridge University Press.

Di Cosmo, N. 2011. Ethnogenesis, Coevolution and Political Morphology of the Earliest Steppe Empire: the Xiongnu Question Revisited. In Brosseder, U., and Miller, B. (eds.), Xiongnu Archaeology: Multidisciplinary Perspectives of the First Steppe Empire in Inner Asia (pp. 35-48) (Bonn Contributions to Asian Archaeology, Vol. 5). Bonn: Rheinische Friedrich-WilhelmsUniversitat Bonn.

Earle, T. 1987. Chiefdoms in Archaeological and Ethnohistorical Perspective. Annual Review of Anthropology 16: 279-308.

Earle, T. 1997. How Chiefs Come to Power: The Political Economy in Prehistory. Stanford, CA: Stanford University Press.

Earle, T. 2011. Chiefs, Chieftaincies, Chiefdoms, and Chiefly Confederacies: Power in the Evolution of Political Systems. Social Evolution \& History 10 (1): 27-54

Golden, P. B. 1982. Imperial Ideology and the Sources of Political Unity amongst the Pre-Činggisid Nomads of Western Eurasia. Archivum Eurasiae Medii Aevi 2: $37-76$.

Golden, P. B. 1992. An Introduction to the History of the Turks Peoples: Ethnogenesis and State Formation in Medieval and Early Modern Eurasia and the Middle East. Wiesbaden: Otto Harrassowitz.

Golden, P. B. 2001. Ethnicity and State Formation in Pre-Činggisid Turks Eurasia. Bloomington: Indiana University, Department of Central Eurasian Studies.

Grinin, L. E. 2006. The Early State and its Analogues. In Grinin, L. E., Bondarenko, D. V., Kradin, N. N., and Korotaev, A. V. (eds.), The Early State, Its Alternatives and Analogues (pp. 85-163). Volgograd: Uchitel. Original in Russian (Гринин, Л. Е. Раннее государство и его аналоги. Раннее государство, его альтернативы и аналоги (с. 85-163) / Под ред. Гринина, Л. Е., Бондаренко, Д. М., Крадина, Н. Н., Коротаева, А. В. Волгоград: Учитель).

Grinin, L. E. 2008. Early State, Developed State, Mature State: The Statehood Evolutionary Sequence. Social Evolution \& History 7 (1): 67-81.

Grinin, L. E. 2009. The Pathways of Politogenesis and Models of the Early State Formation. Social Evolution \& History 8 (1): 92-132.

Grinin, L. E. 2011. Complex Chiefdom: Precursor of the State or Its Analogue? Social Evolution \& History 10 (1): 234-275.

Grinin, L. E., and Korotaev, A. V. 2011. Chiefdoms and Their Analogues: Alternatives of Social Evolution at the Societal Level of Medium Cultural Complexity. Social Evolution \& History 10 (1): 276-335.

Khazanov, A. M. 1981. The Early State Among the Eurasian nomads. In Claessen, H. J. M., and Skalnik, P. (eds.), The Study of the State (pp. 156-173). The Hague, etc.: Mouton.

Khazanov, A. M. 1984. Nomads and the Outside World. Cambridge: Cambridge University Press. 
Khazanov, A. M. 2010. Review of David Sneath, The Headless State: Aristocratic Orders, Kinship Society, and the Misrepresentation of Nomadic Inner Asia. Social Evolution \& History 9 (2): 206-208.

Klyashtorny, S. G. 1964. Ancient Turks Runic Inscriptions as a Source for the History of Central Asia. Moscow: Nauka. Original in Russian (Кляшторный, С. Г. Древнетюркские рунические памятники как источник по истории Средней Азии. Москва: Наука).

Klyashtorny, S. G. 2003. History of Central Asia and Runic Inscriptions. Saint Petersburg: Faculty of Philosophy of Saint Petersburg State University. Original in Russian (Кляшторный, С. Г. История Центральной Азии и памятники рунического письма. Санкт-Петербург: Филологический факультет Санкт-Петербургского государственного университета).

Klyashtorny, S. G. 2010. Runic Inscriptions of Uyghur Khaganate and History of Eurasian Steppes. Saint Petersburg: Izdatelstvo 'Petersburgskoye vostokovedeniye'. Original in Russian (Кляшторный, С. Г. Рунические памятники Уйгурского каганата и история евразийских степей. СанктПетербург: Издательство «Петербургское востоковедение).

Klyashtorny, S. G., and Savinov, D. G. 2005. Steppe Empires of Ancient Eurasia. Saint Petersburg: Faculty of Philosophy of Saint Petersburg State University. Original in Russian (Кляшторный, С. Г., Савинов, Д. Г. Степные империи древней Евразии. Санкт-Петербург.: Филологический факультет СанктПетербургского государственного университета).

Klyashtorny, S. G., and Sultanov, T. I. 2009. The States and Nations of Eurasian Steppes from the Ancientry to the Modern Age. Saint Petersburg: Petersburgskoye vostokovedeniye. Original in Russian (Кляшторный, С. Г., Султанов, Т. И. Государства и народы евразийских степей от древности к новому времени. Санкт-Петербург: Петербургское востоковедение).

Kradin, N. N. 1992. Nomadic Societies. Vladivostok: Dalnauka. Original in Russian (Крадин Н. Н. Кочевые общества. Владивосток: Дальнаука).

Kradin, N. N. 1995. Chiefdoms: Contemporary Studies and Problems. In Popov, V. A. (ed.), Early Forms of Political Organizations (pp. 11-61). Moscow: Vostochnaya literatura. Original in Russian (Крадин, Н. Н. Вождество: современное состояние и проблемы изучения. Ранние формы политической организации / Под ред. Попова, В. А. (c.11-61). М.: Восточная литература).

Kradin, N. N. 2002. The Xiongnu Empire. Moscow: Logos. Original in Russian (Крадин, Н. Н. Империя хунну. М.: Логос).

Kradin, N. N. 2003. Nomadic Empires: Origins, Rise, Decline. In Grinin, L. E., Bondarenko, D. M., and Barfield, T. (eds.), Nomadic Pathways in Social Evolution (pp. 73-87). Moscow: Center of Civilizational Studies.

Kradin, N. N. 2006. Archaeological Criteria of Civilization. Social Evolution \& History 5 (1): 89-108.

Kradin, N. N. 2008. Structure of Power in Nomadic Empires of Inner Asia: Anthropological Approach. In Grinin, L. E., Belyaev6 D. D., and Korotayev, A. V. (eds.), Hierarchy and Power in the History of Civilizations: Ancient and Medieval Cultures (pp. 98-125). Moscow: URSS. 
Kradin, N. N. 2009. State Origins in Anthropological Thought. Social Evolution \& History 8 (1): 25-51.

Kradin, N. N. 2010. Structure of Society and Power in the Ancient Inner Asian Nomadic Empires: Xiongnu and Xianbei. In Hamayon, R., Charleux, I., Delaplace, G., and Pearce, S. (eds.), Representing Power in Ancient Inner Asia: Legitimacy, Transmission and the Sacred (pp. 307-341). Bellingham: Western Washington University Press.

Kradin, N. N. 2011a. Liao Dynasty as a Nomadic Empire. The International Conference on 'Cultural Diversity of Nomads' (pp. 25-34). Ulaanbaatar: International Institute for the Study of Nomadic Civilizations.

Kradin, N. N. 2011b. Nomadic Empires in Evolutionary Perspective. In Kradin, N. N., Korotayev, A. V., and Bondarenko, D. M. (eds.), Alternatives of Social Evolution (pp. 425-449). $2^{\text {nd }}$ ed. Saarbrükken: Lambert Academic Publishing.

Kradin, N. N. 2011c. Stateless Empire: The Structure of the Xiongnu Nomadic Super-Complex Chiefdom. In Brosseder, U., and Miller, B. (eds.), Xiongnu Archaeology: Multidisciplinary Perspectives of the First Steppe Empire in Inner Asia (pp. 77-96) (Bonn Contributions to Asian Archaeology, Vol. 5). Bonn: Rheinische Friedrich-Wilhelms-Universität Bonn.

Kradin, N. N. 2011d. Medieval Towns of Nomadic Empires of Mongolian Steppes. Sredniye veka 72 (1-2): 330-351. Original in Russian (Крадин, Н. Н. Города в средневековых кочевых империях монгольских степей. Средние века 72 (1-2): 330-351).

Kradin, N. N. 2014. Nomads of Inner Asia in Transition. Moscow: URSS.

Kradin, N. N. 2015. Nomadic Empires in Inner Asia. In Bemmann, J., Schmauder, M., Brosseder, U., Reichert, S., and Stickler, T. (eds.), Complexity of Interaction Along the Eurasian Steppe Zone in the First Millennium CE (pp. 11-48) (Bonn Contributions to Asian Archaeology, Vol. 7). Bonn: Rheinische Friedrich-Wilhelms-Universität Bonn.

Kradin, N. N., and Ivliev, A. L. 2014. History of the Khitans Liao Empire. Moscow: Nauka, Vostochnaya literatura. Original in Russian (Крадин, Н. Н., Ивлиев, А. Л. История киданьской империи Ляо. М.: Наука, Восточная литература).

Kradin, N. N., Ivliev, A., Vasyutin, S. A., Kharinsky, A. V., Ochir, A., Kovychev, E. V., and Erdenebold, L. 2017. The Excavation of Tereljin-Durvuldjin Fortress and Some Results of the Study of Xiongnu Urbanization. In Bazarov, B. V., and Kradin, N. N. (eds.), Actual Problems of Archaeology and Ethnology of Central Asia: Materials of the II International Conference (Ulan-Ude, 4-6 ${ }^{\text {th }}$ December, 2017) (pp. 163-175). Ulan-Ude: The Buryat Scientific Center SB RA. Original in Russian (Крадин, Н. Н., Ивлиев, А. Л., Васютин, С. А., Харинский, А. В., Очир, А., Ковычев, Е. В., Эрдэнэболд Л. Раскопки городища Тэрэлжийн-Дурвулжин и некоторые итоги изучения хуннской урбанизации / под ред. Базарова, Б. В., Крадина, Н. Н. Актуальные проблемь археологии и этнологии Центральной Азии: Материалы II Международной конференщии (Улан-Удэ, 4-6 декабря, 2017) (c. 163-175). Улан-Удэ: Бурятский научный центр СО РАН). 
Kradin, N. N., and Skrynnikova, T. D. 2006. Chinggis Khan Empire. Moscow: Vostochnaya literatura RAN. Original in Russian (Крадин, Н. Н. Скрынникова, Т. Д. Империя Чингис-хана. М.: Восточная литература РАН).

Legrand, J. 2011. Mongols et Nomades: Societe, Histoire, Culture. Text, Communications, Articles 1973-2011. Ulaanbator.

Liu Mau-tsai, 1958. Die Chinesischen Nachrichten zur Geschichte der Ost-Türken (T'u-küe). B. I. Texte. Wiesbaden: Otto Harrassowitz.

Mackerras, C. 1990. The Uyghur. In Sinor, D. (ed.), The Cambridge History of Early Inner Asia (pp. 317-342). Cambridge: Cambridge University Press.

Mackerras, C. 2000. Uygur-Tang relations, 744-840. Central Asian Survey 19 (2): 223-234.

Mackerras, C. 2004. Relations between the Uyghurs and Tang China, 744-840. Journal of Turks Civilization studies 1: 95-108.

Malov, S. E. 1951. Ancient Turks Inscriptions. Moscow - Leningrad: Izdatelstvo AN SSSR. Original in Russian (Малов, С. Е. Памятники древнетюркской письменности. М. - Л.: Издательство АН СССР).

Malov, S. E. 1959. Ancient Turks Inscriptions of Mongolia and Kirghizia. Moscow - Leningrad: Izdatelstvo AN SSSR. Original in Russian (Малов, C. E. Памятники древнетюркской письменности Монголии и Киргизии. М. Л.: Издательство АН СССР).

Rogers, D. 2007. The Contingencies of State Formation in Eastern Inner Asia. Asian Perspectives 46 (2): 249-274.

Rogers, D. 2011. Inner Asian States and Empires: Theories and Synthesis. Journal of Archaeological Research 20: 205-256.

Rogers, D. 2018. Strategies of Empire Expansion. In Dürinc, B. S., and Stek, T. D (eds.), The Archaeology of Imperial Landscapes: A Comparative Study of Empires in the Ancient Near East and Mediterranean World (pp. 301-323). Cambridge: Cambridge University Press.

Rogers, D., Erdenebat, U., and Gallon, M. 2005. Urban Centres and the Emergence of Empires in Eastern Inner Asia. Antiquity 79: 801-818.

Sinor, D. 1990. The Establishment and Dissolution of the Türk Empire. In Sinor, D. (ed.), The Cambridge History of Early Inner Asia (pp. 285-316). Cambridge: Cambridge University Press.

Skalnik, P. 2009. Early State Concept in Anthropological Theory. Social Evolution \& History 8 (1): 5-24.

Skalnik, P. 2011. Chiefdom at War with Chiefless People While the State Looks on. Evolution \& History 10 (1): 55-121.

Sneath, D. 2007. The Headless State: Aristocratic Orders, Kinship Society, and Misrepresentations of Nomadic Inner Asia. New York: Columbia University Press.

Sneath, D. 2009. Tribe, Ethnos, Nation: Rethinking Evolutionist Social Theory and Representations of Nomadic Inner Asia. Ab Imperio 4: 80-109.

Scheidel, W. 2011. The Xiongnu and the Comparative Study of Empire In Brosseder, U., and Miller, B. (eds.), Xiongnu Archaeology: Multidisciplinary Perspectives of the First Steppe Empire in Inner Asia (pp. 111-120). 
Bonn Contributions to Asian Archaeology, Vol. 5. Bonn: Rheinische Friedrich-Wilhelms-Universität Bonn.

Taskin, V. S. 1984 (trans.). The Materials on the History of the Ancient Nomadic Peoples Tung-hu. Moscow: Nauka. Original in Russian (Таскин, В. С. (перевод). Материаль по истории кочевых народов группы дунху. Москва: Наука).

Tiuriumina, L. V. 2007 (transl.). History of the Iron Empire. Novosibirsk: Izdatel'stvo Instituta arheologii and etnografii SO RAN. Original in Russian (История Железной империи. Перевод с китайского Л. В. Тюрюминой / под ред. Ларичева, В. Ю. Новосибирск: Издательство Института археологии и этнографии СО РАН).

Vasyutin, S. A. 2003. Typology of Pre-States and Statehood System of Nomads. In Kradin, N. N., Bondarenko, D. M., and Barfield, T. (eds.), Nomadic Pathways in Social Evolution (pp. 50-62). Moscow: Center of Civilizational Studies.

Vasyutin, S. A. 2010. The Main Models of Power Organization in Nomads of Central Asia in the Middle Ages (in Terms of the Multi-linearity Theory). Oriens 4: 20-34. Original in Russian (Васютин, С. А. Основные модели организации власти у кочевников Центральной Азии периода раннего средневековья (в свете теории многолинейности). Восток 4: 20-34).

Vasyutin, S. A. 2015a. Traditional and Innovative Mechanisms of Governing in Nomadic Societies of Central Asia in the Sixth - the Thirteenth centuries. Part 2. Vestnik Kemerovskogo Gosudarstvennogo Universiteta 1 (61) Vol. 3: 20-26). Original in Russian (Васютин, С. А. Традиционные и инновационные механизмы управления в кочевых обществах Центральной Азии VI-XIII вв. Ч. 2. Вестник Кемеровского государственного университета 1 (61) Т. 3 : 20-26).

Vasyutin, S. A. 2015b. The Model of the Political Transformation of the Dao Liao as an Alternative to the Evolution of the Structures of Authority in the Early Medieval Pastoral Empires of Mongolia. In Bemmann, J., Schmauder M., Brosseder, U., Reichert, S., and Stickler, T. (eds.), Complexity of Interaction Along the Eurasian Steppe Zone in the First Millennium CE (pp. 391-437) (Bonn Contributions to Asian Archaeology, Vol. 7). Bonn: Rheinische Friedrich-Wilhelms-Universität Bonn.

Vasyutin, S. A. 2015c. Nomads Towns as a Factor of Social and Political Transformations. In Bazarov, B. V. (ed.), Actual Problems of Archaeology and Ethnology of Central Asia: Materials of the II International conference (UlanUde, 7-8 th April, 2015) (pp. 223-231). Irkutsk: 'Ottisk'. Original in Russian (Васютин, С.А. Города кочевников как фактор социально-политических трансформаций / под ред. Базарова, Б. В. Актуальные вопросы археологии и этнологии Центральной Азии: Материаль Международной научной конференции (Улан-Удэ, 7-8 апреля, 2015) (с. 223-231). Иркутск: «Оттиск»).

Wittfogel, K. A., and Feng, Chia-sheng. 1949. History of Chinese Society. Liao (907-1125). Philadelphia: American Philosophical Society.

Ye Longli. 1979. History of the Khitan State. Transl. from Chinese by Taskin, V. S. Moscow: Nauka. Original in Russian (Е Лун-ли. История государства киданей (Цидань го чжи). Пер. с китайского Таскина, В. С. М.: Наука). 